\title{
ANALYSIS OF VILLAGE EXTENSION AGENTS' ACCESS AND USE OF INFORMATION AND COMMUNICATION TECHNOLOGY IN THE DELIVERY OF EXTENSION SERVICES IN THE CENTRAL AGRICULTURAL ZONE OF PLATEAU STATE, NIGERIA
}

\author{
Vihi S.K. ${ }^{1 *}$, Tor L.G. ${ }^{2}$, Jesse B. ${ }^{1}$, Dalla A.A. ${ }^{1}$, Onuwa G.C. ${ }^{1}$, Haroun M. \\ ${ }^{1}$ Department of Agricultural Extension and Management, Federal College of Forestry of Jos, \\ Plateau State, Nigeria \\ ${ }^{2}$ Department of Agricultural Technology, Federal College of Forestry Mechanization Afaka, \\ Kaduna State, Nigeria \\ *E-mail: vihisam@gmail.com
}

\begin{abstract}
This study examined village extension agent's access and use of information and communication technology in extension services delivery to farmers in Plateau State, Nigeria. The population for the study consisted of all the village extension agents (VEAs) of the Plateau Agricultural Development Program (PADP) in the central agricultural zone of the state. Multistage sampling technique was employed in selecting the respondents for the study. Primary data were collected through the administration of questionnaires and interview techniques and were analyzed using descriptive and inferential statistics. Findings from the study shows that majority $(77 \%)$ of the sampled village extension agents (VEAs) were males with a mean age of 43 years, Majority $(87 \%)$ of the respondents were married with a mean household size of 4 persons. The study also showed that majority $(80 \%)$ of the VEAs had tertiary education with a mean working experience of 13 years and average monthly income of $\$ 64875$. The result also shows that four (4) out of the seven (7) listed ICT facilities were adjudged the ICT facilities accessible to VEAs in the study area having had mean values above the discriminating index ( $\bar{x}=2.50)$. They included; GSM (phone) $(\bar{x}=3.94)$, radio $(\bar{x}=$ $2.83)$, television $(\bar{x}=2.73)$ and computer $(\bar{x}=2.68)$. Based on 2.50 discriminating index, only two out of seven listed conventional ICT facilities had mean values above the discriminating index ( $\bar{x} 2.50)$ and thus were adjudged the ICT facilities used by VEAs. The GSM (phone) had the highest mean value of 3.62 followed by radio with mean value of 2.54 . The logit regression result shows that coefficients of years of working experience and monthly income were significant and positively related to ICT use, while age and complexity in use of ICT were significant and negatively related to ICT use. Major constraints to use of ICT by VEAs includes; lack of administrative support in provision of ICT (87\%), lack of in-service training on ICT use (66\%), Poor salary/remuneration (64\%), lack of awareness of ICT importance in extension (56\%) among others. The study recommends intervention, serious synergy and proactive response on the part of government, non-governmental organization and extension organizations in ICT provision and training of VEAs on ICT use as well as stepping up campaigns on the importance of ICT use in agricultural extension delivery.
\end{abstract}

\section{KEY WORDS}

Village extension agents (VEA), access, information and communication technology (ICT), delivery, extension services.

Sustainable agricultural development cannot be achieved successfully without accurate and up-to-date information and technologies to cope with globalization and its simultaneous rapid technological changes. This is because information is important for the development of any society and success for human endeavor (Sokoya et al., 2014). According to Tiwari and Sharma (2015), information is considered the fifth human need after air, water, food and shelter. Therefore, the concept of agricultural information in general and in particular, as a source of development, is of great importance in the contemporary world and cannot be overemphasized (Ogbonna and Aguvu, 2013). There is hardly an area of human activity today that has not been touched by dramatic changes in information and communication 
technologies (ICT). ICTs, in the broadest sense, are a set of tools, equipment, programs and services that are used to produce, capture, store, disseminate and exchange information (Raji, 2008). Ozor and Madukwe (2009) conceived ICT as a set of technologies that facilitate the processing, storage, retrieval and transmission of information. Information and communication technologies can be broadly defined as technologies that simplify communication, through the process and transmission of information through electronic media (Suleiman et al., 2015).

Adepetun (2012) sees ICT as an essential tool and essential spice for sustainable development, which has the potential to reduce poverty and improve livelihoods by providing timely knowledge to users, reducing transaction costs and improving productivity. Okeke et al., (2015) confirmed that Nigeria today is rich in different forms of ICT devices that are used in different areas as it needs to deal with information explosions. Mukesh et al. (2010) divided ICT into three parts namely; first is broadcast technology-media which includes radio, projectors, media vans, newspapers, magazines, newsletters, leaflets. The second is printing technology which includes newspapers, magazines, newsletters etc. and finally telecommunication/computer technology which include global system and telephones, computers, fax and internet. Information and communication technologies have unique characteristics that allow them to be used in different ways than those used by traditional media for development. According to Agwu et al. (2008), compared to traditional media, ICT provides opportunities for two-way and horizontal communication and opens new channels of communication for rural communities and the intermediaries and development organizations that support them.

ICT increases the ability to search for information and exposes information seekers to diverse information which ultimately reduce uncertainty and broaden market participation. According to the CTA (2000), efficient information transmission is the key to bridging the gap between developed and underdeveloped countries. What to plant, when to plant, how to grow and harvest, where to store and sell, and at what price, depends on long-term knowledge, communication and information exchange. Meera et al. (2004) posited that the emerging new paradigm of agricultural development is calling into question the old ways of providing essential services to citizens as traditional societies are also becoming knowledge based societies around the world. As today's world population grows from 6.7 to 9.1 billion by 2050, food production will need to double over the same period (Tata and McNamara, 2016). Therefore, there is a need for more effective advisory services to address agricultural challenges, including meeting the information needs of poor smallholders in developing countries. In response, agricultural extension professionals and institutions around the world are promoting the use of information and communication technology (ICT) through agricultural extension and education agents.

Agricultural extension which relies heavily on the exchange of information between and among farmers is an area where ICT can have a significant impact. In many Sub-Saharan African countries conventional media such as radio, newspapers and television play a key role in rural development. It is through these media that agricultural innovations are disseminated to rural farmers. Unfortunately, extension agents in Nigeria still rely heavily on traditional methods of disseminating information (Orikpe and Orikpe, 2013). This is no longer effective for limited-time research discoveries and higher farmers-extension agent ratios in the new millennium. At the beginning of the State-wide Agricultural Development Program (ADPs) in 1980, the ratio of extension agents: farmers (EA: farmers) ranged from 1: 2000 to 1: 3000 . This was expected to decrease from 1: 800 to $1: 1000$ by the completion date of the project and the withdrawal of support from the World Bank (Adejo et al., 2013). This goal was never achieved. Based on the results of the 2018 Agricultural Performance Survey (APS) conducted by NAERLS, which was presented to the public by the Minister of Agriculture and Rural Development, Audu Ogbeh, during the World Food Day celebrations on October 16, 2018, several states did not provide data about its farmers and extension agents. However, some few states provided information on farm families in 2018. They include Kano State which recorded the highest number of Village Extension Agents (VEA) of 1,118 followed by Plateau State with 467 VEAs. Ebonyi State recorded 103 VEAs, while Benue and Lagos 
States recorded 27 and 6 VEAs respectively. The number of VEAs is largely insufficient to provide advisory services to farmers even as most states have not conducted a survey on agricultural resources in the past 20 years. With this number, the average farm families' ratio in the country stands at 1:5,000, against FAO's recommended 1:800. From the 2018 APS report, the desire to achieve a ratio of one EA to 1,000 farmers is very far from being a reality, as reports from all the states indicated very high EAs/farmers ratio. Thus, it can be seen that no matter how effective the provision of extension services through extension workers in villages may be, it can never be efficient and cost effective in a developing country like Nigeria with a projected population of over 200 million (National Population Commission, 2006), most of whom are employed in agriculture. Currently, the role of agricultural extension is somewhat in flux, and clouded by uncertainty as to how to meet the challenges of the new wave of information technology.

The inefficiency associated with traditional person-to-person information flow mechanisms, especially in the dissemination of extension messages, has led to the possibility of using ICT as a complementary tool. Meera et al. (2004) stated that as a result of the emergence of new paradigm of agricultural development, the old ways of providing vital services to citizens are being challenged. Traditional societies are also turning into scientific societies all over the world. However, these problems can be alleviated by the effective exploitation of innovative solutions that incorporate information and communication technologies in the dissemination of agricultural information. Meera et al. (2004) reiterate that ICT can be of great help by allowing extension workers to collect, store, retrieve and disseminate the extensive information they need, thus turning them from extension agents into knowledge based workers. The emergence of this knowledge based workers will result in the realization of bottom-up and demand-driven technology generation, assessment, refinement and technology transfer. The Training and Visiting (T\&V) system practiced in Nigeria and other countries has traditionally been supported by ICT facilities such as mobile cinema, video, television, radio and telephone as the main ICT used by most extension workers. From the above, it is clear that some ICT facilities are widely available, but it is not very clear to what extent they are used by extension agents to affect the lives of farmers. Previous research studies have not brought a clear picture of the level of usage of ICT facilities by extension workers especially in Plateau state. According to Arinze et al. (2012), the impact of ICT use in extension delivery in Nigeria still remained minimal. This has resulted in a knowledge gap which needs to be filled. The urgent need for current agricultural knowledge and information system by farmers calls for the adoption of information and communication technologies (ICTs) by extension workers to transmit relevant information to farmers in a most efficient way. The broad objective of the study is to examine village extension agents' access and use of information and communication technology in extension services delivery in Plateau State, Nigeria. The specific objectives were to; describe the socio-economic characteristics of the village extension agents (VEAs) in the study area, assess the level of access of VEAs to ICT facilities in the study area, ascertain the level of use of ICT facilities by the VEAs in extension services delivery, determine the factors influencing the use of ICTs by the VEAs and identify the constraints to the use of ICT facilities by VEAs.

The following null hypothesis shall be tested thus:

- $\mathrm{H}_{0}$ : There is no significant relationship between the socio-economic characteristics of VEAs and their level of use of ICT.

\section{MATERIALS AND METHODS OF RESEARCH}

The study was carried out in Plateau State, located in north central region of the country referred to as the Middle Belt. The state was created in February 1976 when it was carved out of Benue-Plateau State. The state lies between latitudes $8^{\circ} \mathrm{N}$ and $10^{\circ} \mathrm{N}$ and longitude $7^{\circ} \mathrm{E}$ and $11^{\circ} \mathrm{E}$ of the prime meridian (GTZ, 2010). The state has a population of $3,206,531$ based on the 2006 Census (NBS, 2009). The projected population by 2019 stands at 4614434 people going by a population growth rate of $2.8 \%$ per annum. The state shares 
common boundaries with Kaduna and Bauchi States to the North, Benue State to the South, Taraba State to the East and Nasarawa State to the West. The State has 17 Local Government Areas and three senatorial Zones. The senatorial zones are: Plateau North, Plateau Central and Plateau South Senatorial Zones. The altitude ranges from around 1,200 meters (about 4000 feet) to a peak of 1,829 meters above sea level in the Shere Hills range near Jos. Though situated in the tropical zone, a higher altitude means that Plateau State has a near temperate climate with an average temperature of between 18 and $22^{\circ} \mathrm{C}$. Harmattan winds cause the coldest weather between December and February. The warmest temperature usually occurs in the dry season months of March and April. The highest rainfall is recorded during the wet season months of July and August. With $70 \%$ of the population being rural dwellers, it is not surprising that $68 \%$ of the workforce is involved in agriculture.

The population for the study consisted of all the village extension agents (VEAs) of the Plateau Agricultural Development Program (PADP) in the central agricultural zone of the state. A two stage sampling technique was used in selecting the respondents for the study. The first stage involved the purposive selection of Plateau central agricultural zone for the study. The central zone consists of Mangu, Bokkos, Pankshin, Kanke and Kanam Local Government Areas (LGAs) with headquarters in Mangu. In the second and final stage, all the 172 village extension agents (VEAs) available in Plateau central agricultural zone were selected for the study. They includes; 50 VEAs from Mangu, 32 from Bokkos, 43 from Pankshin, 28 from Kanke and 19 from Kanam Local Government Areas. The decision to use $100 \%$ of the extension agents in the selected zone was due to the few number of village extension agents in the zone.

Data for this study was garnered from primary sources. This was achieved through the use of questionnaire structured to capture and elicit information from the respondents based on the objectives and hypotheses of the study. Data for this study was analyzed using descriptive statistical tools such as frequency distribution, percentages, mean score, four point Likert type scale as well as binary logit regression.

The logit regression model is a unit or multivariate technique which allows for estimating the probability that an event occurs or not by predicting a binary dependent outcome from a set of independent variables. The logit model is based on cumulative logistic probability function and it is computationally tractable. According to Gujarati and Porter (2009), it is expressed as (1):

$$
\mathrm{P}_{\mathrm{i}}=\mathrm{E}(\mathrm{Y}=1 \| \mathrm{Xi})=\mathrm{B}_{1}+\mathrm{B}_{2} \mathrm{X}_{2}+\mathrm{B}_{3} \mathrm{X}_{3} \ldots \ldots \ldots \mathrm{B}_{\mathrm{n}} \mathrm{X}_{\mathrm{n}}
$$

For ease of estimation, equation (1) is further expressed as (2):

$$
\mathrm{Pi}=\frac{1}{1+e^{-z i}}=\frac{e^{-z}}{1+e^{-z i}}
$$

Where: $P_{i}=$ probability of an event occurring; $P_{i}=B_{i}+B_{2} X_{i}$.

The empirical model of the logistic regression for study assumed that the probability of the farmers' participation in Agricultural insurance scheme is expressed as (3):

$$
P_{i}=\frac{e^{b_{0}}+b_{1} X_{1}+b_{2} X_{2}+b_{3} X_{3}+b_{4} X_{4}+b_{5} X_{5}+b_{5} X_{5} \ldots+b_{9} X_{9}}{1+e^{b}+b_{1} X_{1}+b_{2} X_{2}+b_{3} X_{3}+b_{4} X_{4}+b_{5} X_{5}+b_{5} X_{5} \ldots+b_{9} X_{9}}
$$

$P_{i}$ ranges between zero and one and it is non-linearly related to $Z_{i}, Z_{i}$ is the stimulus index which ranges from minus infinity to plus infinity and it is expressed as (4):

$$
Z_{\mathrm{i}}=\operatorname{In}\left(\frac{\mathrm{P}_{\mathrm{i}}}{1-\mathrm{P}_{\mathrm{i}}}\right) \mathrm{b}_{0}+\mathrm{b}_{1} \mathrm{X}_{1}+\mathrm{b}_{2} \mathrm{X}_{2} \ldots+\mathrm{b}_{9} \mathrm{X}_{9}+\mathrm{u}
$$


To obtain the value of $Z_{i}$, the likelihood of observing the sample was formed by introducing a dichotomous response variable. The explicit logit model was expressed as (5):

$$
Y=b_{0}+b_{1} X_{1}+b_{2} X_{2} \ldots+b_{9} X_{9}+u
$$

Where:

$Y=$ Pooled index of level of use of ICT by the respondents (Mean index of 2.5 and above = used ICT, index below $2.5=$ not used ICT);

$\mathrm{X}_{1}=$ Age of VEAs (Years);

$X_{2}=$ Sex (Dummy variable, male $=1$, female $=2$ );

$\mathrm{X}_{3}=$ Marital status (Dummy variable, single $=0$, married $=1$ );

$\mathrm{X}_{4}=$ Educational level of farmers (Years of formal education);

$\mathrm{X}_{5}=$ Household size (number of persons);

$\mathrm{X}_{6}=$ Working experience (Years);

$\mathrm{X}_{7}=$ Monthly income (Naira);

$\mathrm{X}_{8}=$ Perception of cost of ICT facilities (1 if high, 0 if otherwise);

$\mathrm{X}_{9}=$ Complexity in use of ICT ( 1 if complex, 0 if otherwise);

$b_{1}-b_{9}=$ Coefficients to be estimated;

$\mathrm{b}_{0}=$ Constant term;

$\mathrm{u}=$ error term.

\section{RESULTS AND DISCUSSION}

Socio-economic characteristics of village extension agents (VEAs). The socioeconomic characteristics of the village extension agents (VEAs) are presented in Table 1. The result showed that $43.0 \%$ of the VEAs were between the ages of $41-50$ years. $32.0 \%$ fell within the age group $31-40$ years. Those above 50 years were next with $19 \%$ while $6 \%$ of the respondents fell within the age range of $21-30$ years of age. The mean age of the VEAs was 43 years. This shows that most of the extension agents are in their economically active and productive ages, hence there is high prospect for ICT usage as they will be able to respond and meet the needs of farmers using variety of communication strategies. This result confirmed the findings of Tologbonse et al.(2011) and Asadu et al.(2013) that a greater proportion of village extension agents (VEAs) were within the age range of $41-50$ years in Niger and Imo States respectively. The result in Table 1 shows that majority (77\%) of the sampled village extension agents (VEAs) in the study area are largely males while only $(23 \%)$ are females. This shows that male VEAs dominate the extension scheme of the ADP system. This agrees with the findings of Adedoyin et al. (1999) that male dominate the workforce in Nigeria's agricultural sector. The dominance of male VEAs could be adduced to the traditional consideration in favor of the male child in almost every facet of the society. Thus, most extension agencies see the male VEAs as utility and valuable workers who can go the extra mile without cultural inhibition. This possibly favors their employment. The result further shows that $87 \%$ of the respondents are married while $13 \%$ are single. This simply implies that most of these VEAs were responsible and had a family to maintain. It should be noted that the basic needs of the family will take priority position in the family budget before ICT will be considered. This finding collaborates the work of Yakubu et al., (2013) who in their study on use of information and communication technologies among extension agents in Kano state, Nigeria reported that the entire (100\%) agricultural extension agents in the area were married implying that most of them are responsible and would be committed to their duties providing reliable and useful information to farmers in the course of their extension service delivery.

The result also shows that $57 \%$ of the VEAs in the study area had a household size of 4-7 persons, 39\% had 1-3 persons while 4\% of the household had more than 7 persons. The mean household size of respondents in the study area was 4 persons. This means that the household size of the extension agents was relatively small. The high literacy level of the 
VEAs and the current economic crunch in the country may be responsible for the modest family size.

Table 1 - Distribution of Respondents Based on their Socio-economic Characteristics ( $n=172)$

\begin{tabular}{|c|c|c|c|}
\hline Variable & Frequency & Percentage & Mean \\
\hline \multicolumn{4}{|l|}{ Age (years) } \\
\hline $21-30$ & 11 & 6.0 & \\
\hline $31-40$ & 55 & 32.0 & \\
\hline $41-50$ & 74 & 43.0 & \\
\hline 50 above & 32 & 19.0 & 43.0 \\
\hline \multicolumn{4}{|l|}{ Sex } \\
\hline Male & 132 & 77.0 & \\
\hline Female & 40 & 23.0 & \\
\hline \multicolumn{4}{|l|}{ Marital status } \\
\hline Single & 150 & 87.0 & \\
\hline Married & 22 & 13.0 & \\
\hline \multicolumn{4}{|c|}{ Educational level } \\
\hline Primary & - & - & \\
\hline Secondary & - & - & \\
\hline Tertiary & 138 & 80 & \\
\hline Post graduate & 34 & 20 & \\
\hline \multicolumn{4}{|c|}{ Household size (number) } \\
\hline $1-3$ & 67 & 39.0 & \\
\hline $4-7$ & 98 & 57.0 & \\
\hline$>7$ & 7 & 4.0 & 4 \\
\hline \multicolumn{4}{|c|}{ Years of work experience } \\
\hline$<5$ & 45 & 26.0 & \\
\hline $6-10$ & 36 & 21.0 & \\
\hline $11-15$ & 31 & 18.0 & \\
\hline $16-20$ & 24 & 14.0 & \\
\hline $21-25$ & 21 & 12.0 & \\
\hline$>25$ & 15 & 9.0 & 13 \\
\hline \multicolumn{4}{|c|}{ Annual farm income (Naira) } \\
\hline $20,000-40,000$ & 25 & 15.0 & \\
\hline $41,000-60,000$ & 33 & 19.0 & \\
\hline $61,000-80,000$ & 62 & 36.0 & \\
\hline $81,000-100,000$ & 35 & 20.0 & \\
\hline$>100,000$ & 17 & 10.0 & 64875 \\
\hline
\end{tabular}

Source: Field survey, 2021.

It is important to note that a large family size may predispose increased consumption. The fund which would have been used to purchase ICT facilities could be consumed in a bid to meet up with the household needs for food, clothing, healthcare etc. However, the modest household size could invariably be an advantage to ICT usage if the income is adequate because the cost of maintaining the family may not be very high. Majority (80\%) of the VEAs had tertiary education while the remaining $20 \%$ of the VEAs had post graduate education. This was expected as the study location is an urban area with high literacy level. The educational level of any extension agent determines the quality of his skill, his cognitive abilities, technical competence and shows how well and appropriate technological innovation can be transferred to farmers. Education has been identified as a catalyst in agriculture and other productive activities because it broadens the mental horizon, influences the totality of the mind and predisposes individuals to new ideas (Ndaghu, 2011). Adequate education therefore could enhance agricultural extension agents' understanding of use of ICTs and sources of information on improved innovation for agricultural practices. The result shows that $26 \%$ of the VEAs had less than 5 years working experience, $21 \%$ had between $6-10$ years working experience while $18 \%$ had between $11-15$ years working experience. Also, $14 \%$ had between $16-20$ years working experience, $12 \%$ had between $21-25$ years working experience while $9 \%$ had more than 25 years of working experience. The mean number of years of working experience was 13 years. The result implies that the VEAs had 
reasonable years of working experience. The VEAs by their reasonable years of working experience could be placed on better pedestal to access and use ICT facilities. The length of time in the job would make it easier for them to analyze the use and potentials of the facilities in extension service delivery. The study of Tologbonse et al (2011) and Asadu et al (2013) also confirmed reasonable years of experience of VEAs as a catalyst in effective dissemination of different agricultural innovations and ICT usage. On the monthly income of the VEAs, the result shows that $36 \%$ of the VEAs earn between $\$ 61,000$ - $\$ 80,000$ monthly, $20 \%$ earn between $\$ 81,000-100,000,19 \%$ earn between $\$ 41,000-60,000,15 \%$ earn between $\$ 20,000-40,000$ while $10 \%$ earn above $\$ 100,000$. The mean monthly income of VEAs in the study area was $\$ 64875$. Based on the average monthly income, it could be difficult for VEAs to obtain some of the ICT facilities on their own after taking care of the basic/physiological needs. This therefore makes government intervention imperative. In this regard, capacity building Programs have become necessary for increased skills and knowledge and subvention for free distribution of these facilities by government to them is essential.

Accessibility of ICT Facilities by VEAs. The result in Table 2 shows the accessibility of ICT facilities to VEAs. Based on 2.50 discriminating index, four (4) out of the seven (7) listed ICT facilities had mean values above the discriminating index $(\bar{x}=2.50)$ and thus were adjudged the ICT facilities accessible to VEAs in the study area. The GSM (phone) had the highest mean value of 3.94 with a standard deviation of 0.23 . This was followed by radio with a mean value of 2.83 and standard deviation of 0.77 , Tv with mean value of 2.73 and standard deviation of 1-33 and lastly computer with a mean value of 2.68 and standard deviation of 1.01. The facilities whose mean score were below the discriminating index $(\bar{x}=2.50)$ included mobile cinema $(\bar{x}=2.44)$, projector $(\bar{x}=2.20)$ and bulletin $(\bar{x}=1.97)$. Supporting the above findings, Adejo and Haruna (2009) observed that rural people have access to ICTs in the decreasing order of phone (GSM), radio, television and computer. The result also confirmed a recent development in Nigeria which shows that GSM is more accessible to the rural people than television owing to the deregulation of the GSM service provision and proliferation of service providers (Adejo et al., 2013). Also confirming the findings, Tologbonse et al (2011) observed that GSM (phone), radio, television, video and computer are major ICT facilities available to VEAs.

Table 2 - Mean Rating of VEAs by Accessibility of ICT facilities for Extension Work. ( $N=172)$

\begin{tabular}{|c|c|c|c|c|c|c|}
\hline ICT facilities & VA (4) $\%$ & $A(3) \%$ & SA (2) & NA (1) & Mean & STD Dev \\
\hline Radio & $38(22.0)$ & $70(41.0)$ & $62(36.0)$ & $2(1.0)$ & 2.83 & 0.77 \\
\hline GSM (Phone) & $162(94.0)$ & $10(6.0)$ & _ & - & 3.94 & 0.23 \\
\hline Computer & $50(29.0)$ & $37(22.0)$ & $65(38.0)$ & $20(12.0)$ & 2.68 & 1.01 \\
\hline Mobile cinema & a22(13.0) & $72(41.8)$ & $39(22.6)$ & $39(22.6)$ & 2.44 & 0.98 \\
\hline TV & $81(47.0)$ & $18(10.4)$ & 19(11.0) & $54(31.3)$ & 2.73 & 1.33 \\
\hline Bulletin & $9(5.2)$ & $43(25.0)$ & $54(31.3)$ & $66(38.3)$ & 1.97 & 0.92 \\
\hline Projector & $5(3.0)$ & $47(27.0)$ & $98(57.0)$ & $22(13.0)$ & 2.20 & 0.69 \\
\hline
\end{tabular}

Note: $V A=$ Very Accessible, $A=$ Accessible, $S A=$ Scarcely Accessible \& NA= Not Accessible.

Level of Use of ICT Facilities. The result in Table 3 shows the VEAs level of ICT use. Based on 2.50 discriminating index, only two (2) out of seven (7) listed conventional ICT facilities had mean values above the discriminating index ( $\mathrm{x} 2.50)$ and thus were adjudged the ICT facilities the VEAs used. The GSM (phone) had the highest mean value of 3.62 with a standard deviation of 0.72 . This was followed by radio with mean value of 2.54 and standard deviation of 0.97 . The facilities whose mean scores were below the discriminating index included TV $(\bar{x}=1.93)$, computer $(\bar{x}=1.62)$, mobile cinema $(\bar{x}=1.22)$, bulletin $(\bar{x}=2.11)$ and projector $(\bar{x}=1.83)$. This result indicates that VEAs' use of ICT facilities was low. It was 
discovered from personal interview with extension agents in the study area that, the State ADP had no functional ICT unit and internet facility in their office complex. This could be adduced to be responsible for the limited use of some of these ICT facilities by VEAs. Most of the VEAs noted that the poor level of use of ICT facilities is attributable to the lack of administrative support in provision of ICT and low or non-inclusion of ICT in their pre-service training. The study by Adejo and Haruna (2009), Asadu et al (2013) and Adejoet al. (2013) also confirmed that GSM (phone), radio, television and computer are the major ICT facilities used by extension workers across Nigeria. However, extension agents need to go beyond the use of these known ICT facilities to the other ICT facilities whose use were found to be limited. In India, extension workers and rural farmers now use internet, website and their personal e-mail account to access and gather technical information from various research sources to improve their production capacity (Sharma, 2007). It should be noted that agricultural extension service which involved teaching, research and the transfer of new farming technologies and information to farmers and feedback from farmers is one major area where ICT can cause a major noticeable turnaround. According to Wahab et al (2013) who assessed the geographic information system for sustainable agricultural extension service, extension personnel and farmers can use the GIS in weather prediction that will eventually improve agricultural production and monitor market trends. Babalola (2010) noted that GIS can be used to monitor farmers" activities in rural areas.

Table 3 - Mean Rating of Level of Use of ICT facilities by VEAs for Extension Work ( $N=172)$

\begin{tabular}{lllllll}
\hline ICT facilities VO (4) & O (3) & S (2) & \multicolumn{2}{l}{ N(1) } & \multicolumn{2}{l}{ Mean $(\overline{\mathbf{x}})$ STD Dev } \\
\hline Radio & $31(12.0)$ & $64(34.0)$ & $44(31.0)$ & $33(23.0)$ & 2.54 & 0.97 \\
GSM (Phone) & $129(75.0)$ & $24(14.0)$ & $15(9.0)$ & $3(2.0)$ & 3.62 & 0.72 \\
Television & $8(5.0)$ & $22(13.0)$ & $91(53.0)$ & $50(29.0)$ & 1.93 & 0.77 \\
Computer & $1(0.5)$ & $6(3.0)$ & $92(53.0)$ & $72(42.0)$ & 1.62 & 0.58 \\
Mobile cinema & & $12(7.0)$ & $48(28.0)$ & $111(64.5)$ & 1.22 & 0.62 \\
Bulletin & $3(2.0)$ & $44(53.0)$ & $92(53.0)$ & $32(19.0)$ & 2.11 & 0.71 \\
Projector & & $28(16.0)$ & $84(49.0)$ & $59(34.0)$ & 1.83 & 0.69 \\
\hline
\end{tabular}

Note: $V O=$ Very often, $O=$ Often, $S=$ Sometimes $\& N=$ Never used.

Factors Influencing the Use of ICT by VEAs. Table 4 shows the regression analysis of the socio-economic and institutional factors that influence ICT use by VEAs. The coefficients of years of working experience and monthly income were significant and positively related to ICT use, while age and complexity in use of ICT were significant, but negatively related to ICT use.

Age $\left(X_{1}\right)$ was significant and negatively related to ICT use at $10 \%$ level of probability. This means that any increase in age of the VEAs would causes a decrease in ICT use. Advancement in age may lead to lack of interest caused by long hours of working with the computer. The drive for the use of ICT facilities could be lower with decreasing age. This confirmed the findings of Asadu et al. (2013) in a study on communication techniques used by extension workers. They observed that extension workers in their active age are able to respond and meet the needs of farmers using variety of communication strategy.

Years of working experience $\left(X_{6}\right)$ was significant at $5 \%$ level of probability and positively related to ICT use. It implies that as the respondents increase in working experience (skill and knowledge), their ICT use would increase. Thus the respondents' 
practical knowledge and exposure to ICT- based facilities is enhanced. The accumulation of research knowledge and skill will help them become active researchers and learners. The study by Tologbonse et al (2011) also confirmed reasonable years of experience of VEAs as a better pedestal for the adoption of ICT in extension service delivery.

On monthly income $\left(X_{7}\right)$, it was found to be a positively significant factor influencing ICT usage by the respondents. By implication, it means the more income the respondents earn, the higher the tendency for them to utilize ICT. The significant relationship between income and the use of ICT facilities implies that the higher the income, the higher the likelihood of using ICT facilities. This could also mean a high motivation for VEAs to seek for other ICT facilities that were not available but could aid their service delivery.

The coefficient for complexity in use of ICT $\left(\mathrm{X}_{9}\right)$ was significant but negatively related to use of ICT. By implication, it means the more the VEAs perceives complexity in use of ICT, the lower the tendency for them to utilize ICT. The significant relationship between complexity in use of ICT and the use of ICT facilities implies that the higher the complexity, the lower the likelihood of using ICT facilities.

Table 4 - Logit regression estimates of factors influencing use of ICT by VEAs

\begin{tabular}{lllll}
\hline Variable & Coeff. & Std. Err. & $\mathbf{Z}$ & $\mathbf{P}>|\mathbf{z}|$ \\
\hline Constant & -1.284 & 12.672 & -0.10 & 0.919 \\
Age & -6.487 & 3.865 & $-1.68^{*}$ & 0.093 \\
Sex & -.179 & .428 & -0.42 & 0.675 \\
Marital status & .390 & .626 & 0.62 & 0.532 \\
Educational status & 2.998 & 5.357 & 0.56 & 0.576 \\
Household size & -.284 & 1.320 & -0.22 & 0.830 \\
Working experience & 3.736 & 1.628 & $2.30^{* * *}$ & 0.022 \\
Monthly income & 2.049 & .604 & $3.39^{* * *}$ & 0.001 \\
Cost of ICT facilities & 1.103 & 1.788 & 0.62 & 0.537 \\
Complexity in use of ICT & -1.794 & .589 & $-3.04^{* * *}$ & 0.002 \\
Log likelihood = -71.826 & & & & \\
Pseudo R ${ }^{2}=0.101$ & & & & \\
LR chi2(9) $=$ 22.53 & & & & \\
Prob $>$ chi2 = 0.0074 & & & & \\
No. of Observations $=172$ & & & &
\end{tabular}

Note: * " ${ }^{* *}$ and ${ }^{* * *}=$ Significant at $10 \%, 5 \%$ and $1 \%$ probability levels respectively.

Test of Hypothesis. Result of the logit regression in Table 4 reveals that three of the socio-economic variables; age, years of working experience and monthly income were found to have significant relationship with ICT use by VEAs. This goes to show that these variables have a significant effect on the level of use of ICT by VEAs. We therefore reject the null hypothesis and accept the alternative hypothesis, thereby concluding that, there is significant relationship between the socio-economic characteristics of VEAs and their level of use of ICT.

Constraint to Use of ICT Facilities. The constraints to VEAs use of ICTs are presented in Table 5. The results shows that lack of administrative support in provision of ICT ranked first with $87 \%$ followed by lack of in-service training on ICT use (66\%), Poor salary/remuneration (64\%), lack of awareness of ICT importance in extension (56\%), complexity in the use of ICT (45\%), erratic and fluctuating power supply (42\%), nonaccessibility of some ICT facilities (27\%), lack of internet access in rural areas $(22 \%)$ and poor communication network (10\%).

Supporting the above findings, Asadu et al. (2013) observed that illiteracy among farmers, limited power supply, high cost of modern communication techniques, complexity of use, limited network services, lack of access to modern communication techniques and lack of skill among the extension agents constitute serious constraints to the use of ICT facilities by VEAs in Niger State. Asadu et al. (2013) opined that these constraints are more serious in rural areas. The use of GSM (phone), computer and television is common but it is also constrained by limited network coverage, poor connectivity and poor power supply. 
Adebowale (2009) opined that poverty and low computer literacy constitute major challenges to the use of modern communication techniques in agricultural extension delivery services in Nigeria. Poor remuneration of VEAs could constitute a serious limitation to ICT use. VEAs with a mean monthly income of N64, 000 may not be able to fund ICT usage. The use of ICT facilities for research and extension communication remains low because research and extension organizations seem not to be fully ICT ready. Extension organizations do not provide ICT facilities in their offices. This calls for government and non-governmental organizations (NGOs) intervention in providing ICT facilities for VEAs and ensuring increased skills and competence through training.

Table 5 - Constraints to use of ICT facilities by VEAs for Extension Work ( $N=172)$

\begin{tabular}{llll}
\hline Constraints & Frequency & Percentage & Rank \\
\hline Poor salary/remuneration & 111 & 64.0 & $3^{\text {rd }}$ \\
Lack of awareness of ICT importance & 97 & 56.0 & $4^{\text {th }}$ \\
Complexity in using ICT & 77 & 45.0 & $5^{\text {th }}$ \\
Non accessibility of some ICT facilities & 46 & 27.0 & $7^{\text {th }}$ \\
Lack of internet access in rural areas & 38 & 22.0 & $8^{\text {th }}$ \\
Poor/no communication network & 17 & 10.0 & $9^{\text {th }}$ \\
Lack of in-service training on ICT use & 115 & 66.0 & $2^{\text {nd }}$ \\
Lack of administrative support in provision of ICT & 150 & 87.0 & $1^{\text {st }}$ \\
Erratic and fluctuating power supply & 73 & 42.0 & $6^{\text {th }}$ \\
Perception of cost of ICT facilities & 11 & 6.0 & $10^{\text {th }}$ \\
\hline
\end{tabular}

Note: Multiple responses.

\section{CONCLUSION AND RECOMMENDATIONS}

This study examined the village extension agent's access and use of information and communication technology in extension services delivery to farmers in Plateau State, Nigeria.

The study revealed that majority of the farmers were middle aged and active, married and had formal education. They had many years of working experience. The study revealed that accessibility and use of ICT facilities by VEAs in the study area was very low. The ICT facilities accessible to VEAs includes; GSM (phone), radio, television (TV) and computer. The ICT facilities adjudged to be used by VEAs were the GSM (phone) and radio. The logit regression result of factors influencing use of ICT by VEAs shows that coefficients of years of working experience, monthly income, age and complexity in use of ICT were significant and related to ICT use at various levels of probabilities. Major constraints to use of ICT by VEAs includes; lack of administrative support in provision of ICT, lack of in-service training on ICT use, Poor salary/remuneration, lack of awareness of ICT importance in extension, complexity in the use of ICT, erratic and fluctuating power supply, non-accessibility of some ICT facilities, lack of internet access in rural areas and poor communication network. The following recommendations were made based on the findings from the study:

- The Federal Ministry of Agriculture and Rural Development in conjunction with the state ADPs should mount education campaigns on the importance of ICT use in agricultural extension delivery to sensitize VEAs and increase their quest for knowledge and improved skills;

- The states" Agricultural Development Program should provide training and development opportunities on ICT use to increase the knowledge, skills and competence of VEAs in the use;

- The pre-service training curriculum of prospective VEAs should be enriched with ICT to prepare them for the world of work in the extension service;

- As a matter of policy, each state ADP should have a functional ICT center containing relevant facilities to extension service. Also, NGOs in their intervention could provide some or all of the facilities to keep extension work on course. 


\section{CONFLICT OF INTERESTS}

The authors have declared no conflict of interest.

\section{REFERENCES}

1. Adebowale, O.A.L. (2009). Information and communication technology: Its potentials for enhanced agricultural extension service and rural development. In J.U. Agbamu, (Ed) Perspectives in agricultural extension and rural development. Asaba, Nigeria: Spring Field Publishers Ltd, pp. 210-240.

2. Adedoyin, S.F., Fapojuwo, O.E. \& Torimiro, D.O. (1999). Educational communication materials in agricultural technology production: A survey of extension agents in ljebu area of Ogun State. Proceeding of the Fifth Annual National Conference of the Agricultural Extension Society of Nigeria (AESON), 12th - 14th April.

3. Adejo, P.E. \& Haruna, U. (2009). Access of farmers to ICTs for agricultural development in Bauchi Local Government Area of Bauchi State. Proceedings of the 43rd Annual Conference of the Agricultural Society of Nigeria (ASN), 20th - 23rd October, Abuja, pp. 704-707.

4. Adejo, P.E., Edoka, M.H. \&Adejoh, S.O. (2013). Information and communication technologies and agricultural extension service delivery in Nigeria. Proceedings, 18th Annual National Conference of Agricultural Extension Society of Nigeria. 5th - 9th May. Pp 24-32.

5. Adepetun A. (2012). Accelerating broad band penetration through USPF Support. The Guardian Newspaper 1st August. Compulife pp. 25.

6. Agwu A.E; U.C. Uche-Mba, O.M. Akinnagbe (2008). Use of Information Communication Technologies (ICTs) among Researchers, Extension Workers and Farmers in Abia and Enugu States: Implications for a National Agricultural Extension Policy on ICTs. Journal of Agricultural Extension, Vol. 12 (1) June, 2008.

7. Arinze, F.O. Okonkwo, E.N; Iwunor, A.N. (2012). Information and communication technology (ICT) Application in secondary schools and student's academic performance in Social Studies. African Research Review 6 (4):27.

8. Asadu, A.N., Oguwuike, W.T. \& Enwelu, I.A. (2013). Communication techniques used by extension workers in disseminating agricultural information in Imo State, Nigeria. Proceedings, 18th Annual National Conference of Agricultural Extension Society of Nigeria. 5th- 9th May. Pp 47-54.

9. Babalola, O.O. (2010). The challenge of changing trends in the development and use of information and internet web communication technologies for veterinary medicine education in Nigeria. Accessed 04/06/2014 from www.knowledge.cta.int.

10. CTA (2000). CTA Annual Report. CTA, Netherlands.

11. German Technical Cooperation (GTZ) (2010). A Profile of the Plateau State Economy. Baseline Survey Report. July, 2010.

12. Meera, S.N., Jhamtani, A., \& Rao, D.U.M. (2004). Information and communication technology in agricultural development: A comparative 107 analysis of three projects from India. Agricultural Research and Extension Network Paper No. 135. Pp. 20.

13. Mukesh, P., Deepati, T.P and Kanini, B. (2010). ICT for agriculture technology dissemination (http:pagropedia:litk.ac.in//aq=content//ICT-agriculture-technologydissemination) Accessed23/11/2011.

14. National Agricultural Extension and Research Liaison Services (NAERLS) (2012). Executive Summary of Agricultural Performance Survey of 2012 Wet Season in Nigeria. October, 15.

15. National Bureau of Statistics (NBS) (2009). Social Statistics in Nigeria-2010.

16. Ndaghu, A. A., 2011, Use of Information and Communication Technologies (ICTs) among Women Farmers in North-Eastern Nigeria. An unpublished doctoral thesis, University of Ibadan, Nigeria. 
17. Ogbonna, O.I.; Agwu, A.E. (2013). Access and use of Information communication Technologies by Rural Farmers in Enugu North Senatorial Zone, Enugu State. Journal of Agricultural Science 3 (7): 264-270.

18. Okeke, M.N., H.U. Nwalieji and Uzuegbunam, C.O. (2015). Emerging Role of Information Communication Technologies in Extension Service Delivery in Nigeria: A Review. Journal of Agricultural Extension. A publication of AESON, vol. 19(1) June 2015. ISSN 1119944X, p132-141.

19. Orikpe, E. A. and Orikpe, G. O. (2013). Information and communication technology and enhancement of agricultural extension services in the new millennium Journal of Educational and Social Research Vol. 3 (4) July, pp. 155-159.

20. Ozor, N. and Madukwe, M. C. (2009). Role of information communication technology in agricultural development. In Echezona, B. C. (ed.). General Agriculture: Principles and Practices, Faculty of Agriculture, University of Nigeria, Nsukka. Pp. 20-24.

21. Raji, A.O. (2008), The Role of Information and Communication Technologies in Revitalizing Agriculture in Nigeria. Paper presented at the First National Conference on Revitalizing Agriculture for Sustainable National Growth and stable Democracy, at AkperanOrshi, College of Agriculture Yandev, Benue State, Nigeria, October 22-23.

22. Sharma, V.P. (2007). Cyber extension: Changing the face of India agriculture. Manage Extension Research Review. Accessed 30/05/2014 from www.manage.gov.in.

23. Sokoya, A. A; Adefunke, O. A and Fagbola, B.O. (2014). Farmers Information Literacy and Awareness towards Agricultural produce and Food security: FADAMA111 Program in Osun State, Nigeria. African Journal of Agricultural Research vol. 4(12).

24. Tata, J. S. and McNamara, P. E. Social Factors That Influence Use of ICT in Agricultural Extension in Southern Africa. Agriculture 2016, 6, 15; doi:10.3390/agriculture6020015 www.mdpi.com/journal/agriculture.

25. Tiwari, M., Tiwari, N.S. and Sharma, R. (2015). Information and communication technology in academic libraries: how they are important today? International Journal of Applied Research 2015; 1(11): 668-672.

26. Tologbonse, E.B., Olaleye, R.S., Kezi, D.M., Onu, R.O., Okwori, E. \&Shehu, B.M. (2011). Assessment of the level of use of Information and Communication Technology (ICT) facilities by village Extension Agents of Niger State Agricultural Development Project. Proceedings 16th Annual National Conference of Agricultural Extension Society of Nigeria. 21st - 24th March. Pp 129-139.

27. Wahab, A.A., Ismail, F.O., Baba, D., Ladan, E.O., Tenuche, S.S.L., Durojaiye, A.A., Yakubu, B. Musa \& M. Safiyanu (2013). Exploring Geographic Information System for sustainable agricultural extension service in Nigeria. Proceedings 18th Annual National Conference of Agricultural Extension Society of Nigeria (AESON) 5th - 9th May. Pp 230237.

28. Yakubu, D. H., Abubakar, B. Z., Atala,T. K., Muhammed, A., 2013, Use of Information and Communication Technologies among Extension Agents in Kano State, Nigeria. Journal of Agricultural Extension 17 (1): 162 - 173. 